\title{
COMPARISON OF CHOSEN WIND ENERGY ASPECTS OF VISEGRAD COUNTRIES IN CONTEXT OF EU SUSTAINABLE ENERGY SECTOR DEVELOPMENT MANAGEMENT
}

\begin{abstract}
The purpose of this paper is a comparison of chosen wind Energy sectors aspects in Visegrad Group countries, which is not found in the subject' literature. Authors show basic concepts of Energy sector development management based on literature review. It has been indicated that there is no joint decisive voting action in EU of the ally, which consequently leads to lack of common, homogenous Energy policy and weakens a position of V4 as a whole, leaving each of the member individual and separated in their efforts to maintain sustainable Energy development. Authors perform a characteristics of a specified issues of Energy areas and share of wind Energy in it, basing on conducted research and analysis of statistical historical data in order to compare them. Moreover, areas of possible growth and development directions are shown, basing on geographical specification. The paper is constructed as follows: introduction, Energy sector development management issues, characteristics and comparison of Visegrad countries wind Energy, conclusions.
\end{abstract}

Keywords: Visegrad wind Energy, Energy development, Energy policy, sustainable Energy sector development.

\section{INTRODUCTION}

Energy policy shapes ways of future economic growth and development, especially electricity and heating segments. It also affects fuels sector connected to mining and gas systems, but also industries of their distribution and expenditure. Moreover, it influences national Renewable Energy Sources (RES) sector. (Sviteková, Pavolová, Hlavňová, 2014) Its' objective is to create conditions that allow to conduct efficient Energy management while aiming to maximize yield and security. Its' basic element is to manage efforts being undertaken to maintain effective development. Implementation of specific legal solutions allows to align national economies course on the right track in order to care about sustainable development in a competitive environment. Today sustainability concepts are, in the end, focusing on improving quality of life, which can be achieved by intelligent

${ }^{1}$ Jan Polaszczyk, MSc, Faculty of Management, Rzeszów University of Technology; e-mail: j.polaszczyk@prz.edu.pl. ORCID: 0000-0001-5378-5778.

2 Karolina Markiewicz, BEng, Faculty of Metals Engineering and Industrial Computer Science, AGH University of Science and Technology; e-mail: karolinamarkiewicz97@gmail.com (corresponding author). ORCID: 0000-0001-8608-0141. 
generation and distribution of resources in areas such as residential, industrial and commercial fields driven by humans. All that - connected in a planned scheme which should breed fruits in a long perspective, with mentioned ultimate goal of satisfying societies needs and improving their quality of life. Given that, development is a continuous process, described as a series of actions or steps taken in order to achieve a particular result. However, result is never achieved since the expected standards and demands only rise, according to basic economic laws, which on the other hand leads to continuous development.

In order to achieve intended result a cooperation of national economies on a maximum number of fields is essential. That should provide a synergy effect and make taking advantage of greater benefits possible for all stakeholders. It can be achieved by agreeing to common, consistent Energy policy considering all of so different needs of Visegrad Group countries (V4: Poland, Slovakia, Czechia, Hungary). Such efforts should be based on internal regulations, regulations between members but also regulations that are decisive for the whole V4 in context of their presence in EU. Shaping of that policy requires time and workload of every Visegrad Four state. Main guidelines for described denouement are illustrated on Fig. 1.

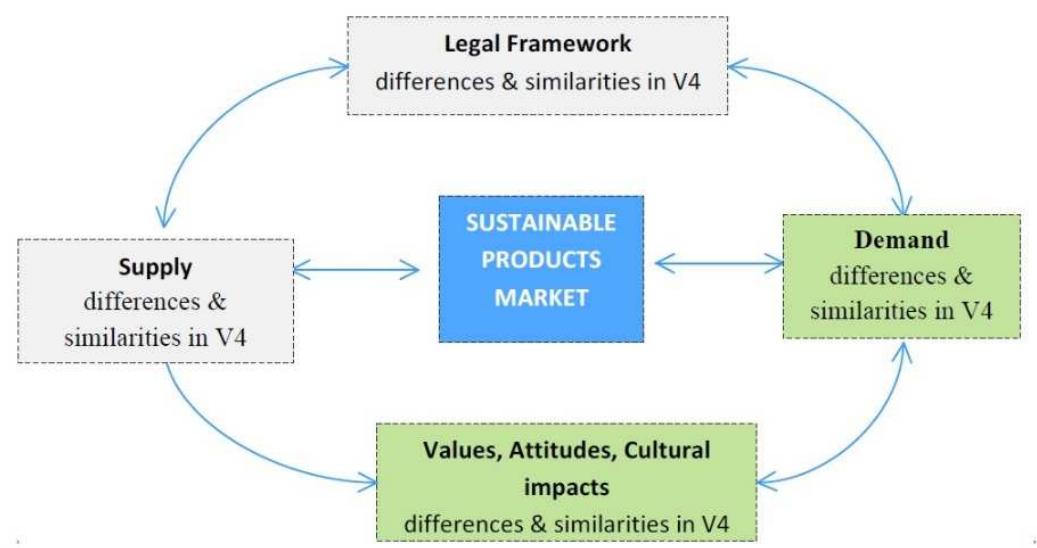

Fig. 1. Guidelines for the joint V4 strategy for solving ecological and social problems of V4 countries

Source: (Koszewska, Militký, Mizsey, Benda-Prokeinova, 2015).

F. Tereszkiewicz (2018) points on divided character of V4 members interest, which consists of two groups: pro environmental policy (Jobbik, SPD and SNS parties) who agree with Paris COP 21 and anti (Wolność, KNP RN, SSO and LSNS parties), who describe climate change as a fabrication of scientists. Whichever opinion, both agree that EU policy about that matter is far from effective and is considered needing a revision. Furthermore, Cetkovic and Buzogany (2019) researched about V4 voting at EU environmental policies and concluded that Poland and Hungary voted negatively most often on emissions, air pollution and renewables, while Czech Republic and Slovakia voted against Energy efficiency projects, where first two mentioned voted for. Described situation shows an example of an overwhelming lack of common Energy policy in V4, driven by countries' 
well-understood self-interest. Each V4 country may tend to see market integration as the implementation of its own market rules at the regional level. With no institutional mechanisms to bring these different positions closer together, the V4 has been unable to find a way forward here. (Osičkaa, Lehotskýa, Zapletalováa, Černocha, Dančák, 2018).

Irrevocable element of European Energy systems is the wind Energy as a source of green Energy for both households and industry consumers. It also becomes ever greater part of so called Polish „Energy mix” and a proper stimulation of its' development is one of main tasks undertaken by contemporary governments, including V4 members. Environmental and geopolitical conditions could both provide a facilitation and impedimentum to that development. V4 countries, surfacing a significant part of East-Central Europe are currently undergoing Energy sector transition to a greater extent than some of developed economies in Europe, such as Scandinavian countries, Netherlands or Germany. It stands for a great challenge, considering previous, existing conventional national Energy system solutions, where RES in a total of Energy demand was scarce and its' production mostly based on fossil fuels. Therefore, the role of wind Energy development and the efficient management of that process is even more important, which implies a necessity of creation of comparisons as presented in this paper.

\section{ENERGY DEVELOPMENT MANAGEMENT}

Technological development implies constant increase of Energy demand and/or Energy expenditure efficacy solutions demand. That leads to the need of controlling its' production, distribution and consumption. Currently, many innovative solutions are emerging, both technological and system-wise. Considering the above, optimized Energy management, promoting ecological behaviour patterns in many scales seems crucial. Energy management is a subject often undertaken by the literature authors, but it still lacks a homogenous division nomenclature. Development management, or transition management of an economy, assigns important, repeatedly multilateral tasks to the governments in order to achieve sustainable development based on self-sufficiency (Kern, Howlett, 2009, Kemp, Rotmans, 2004). The use of Energy as a global commodity in the process of economic growth is highly significant and Energy consumption is an integral part of economic growth (Streimikiene, Kasperowicz, 2016). Precedent goal of a strategy is to create common Energy system of a maximum yield which uses locally available renewable sources with an uninterrupted evolution of low-emission technologies (Chodkowska-Miszczuk, Kulla, Novotný, 2017). In V4 countries the Energy consumption considerably decreased (the Energy intensity significantly improved) since 1991. The reason of that is mostly the enhancement of the sectoral energy efficiency (Szlávik, Szép, 2017). Nevertheless, that does not mean further action is not needed: on the contrary, regulations and specifics have come intact in shape of EU legislative acts which construct a policy. The outcome of any policy development process, including transition management reform processes, is expected to be linked to the manner in which policy goals and means are (or are not) linked with established policies as a result of the reform effort; thus providing a means of evaluating the actual or predicted success or failure of such efforts (Kern, Howlett, 2009). Therefore, it is possible to measure the percentage of achieved goals and adjust efforts accordingly, increasing or lowering workforce and financial flow through different channels. Fig. 2 shows the basic elements needed to achieve the set goal in a transition of a market into a sustainable Energy system. 


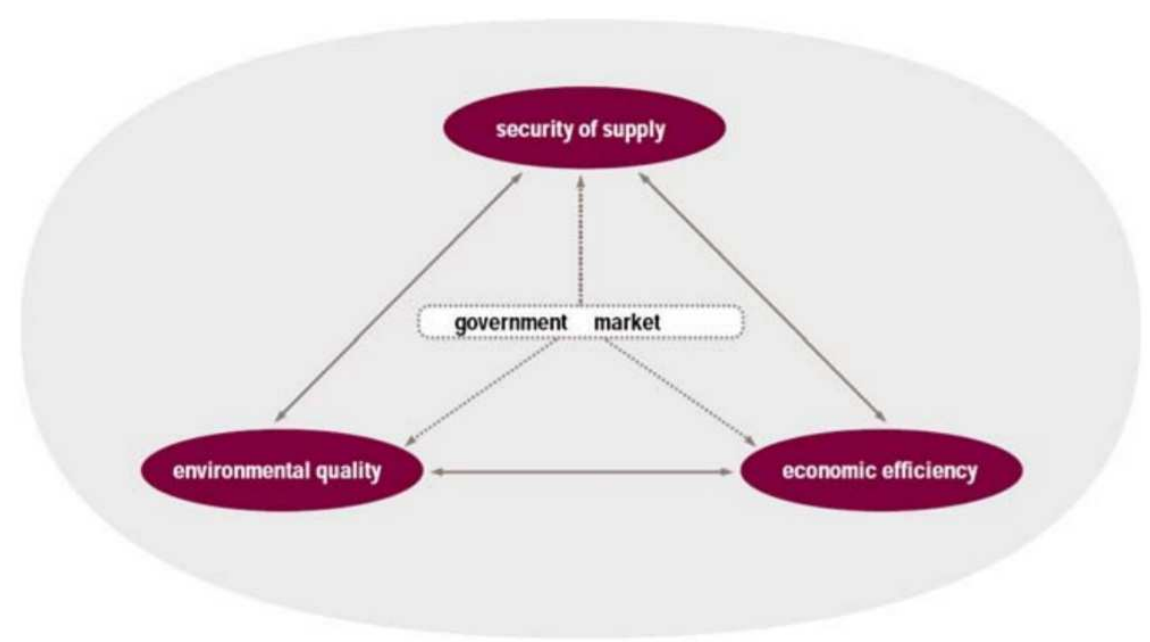

Fig. 2. A sustainable energy system as the goal of energy transition management Source: (Kern, Howlett, 2009).

As defined by the European Parliament, „Energy from renewable sources” or „renewable Energy" means energy from renewable non-fossil sources, namely wind, solar (solar thermal and solar photovoltaic) and geothermal energy, ambient energy, tide, wave and other ocean energy, hydropower, biomass, landfill gas, sewage treatment plant gas, and biogas (Directive (EU) 2018/2001 of The European Parlament and of The Council of 11 December 2018 on the promotion of the use of energy from renewable sources). The diversification plans of the V4 countries stand for trying to change suppliers multiplicity and shares of different Energy sources (fuels) in their mixes, which are different, but share some important characteristics (Dyduch, Skorek, 2020) - mentioned dependence on fossil fuels and imports. Fig. 3 presents Energy mixes for V4 countries.

Analysis of the mixes shows a great dependence on combustion for all V4 members, where Poland is the greatest burner, using $47 \%$ of the primary Energy supply basing on solid fossil fuels (coal) and 28\% on oil in 2017. Czech Republic, on the contrary to Hungary and Slovakia also uses huge amount of those sources. HUN and SK on the other hand depend strongly on natural gas supplies $(32 \%, 24 \%)$ and oil $(28 \%, 21 \%)$. It is needed to indicate that diversity of the sources is worst in Poland, where energy sector mostly depends on coal and lignite.

EU initiative on sustainable development concentrates on three essential targets: reduction of greenhouse gas emissions by $20 \%$, an increase of renewable sources in the EU energy balance by $20 \%$, and a growth of energy efficiency by $20 \%(20-20-20)$ (Pach-Gurgul, Ulbrych, 2019). The objectives, defined in such a way, are based on the three pillars of the EU energy policy, i.e. energy security, competitive markets, and sustainable development. Fig. 4 shows the progress towards those targets up to the year 2016. 

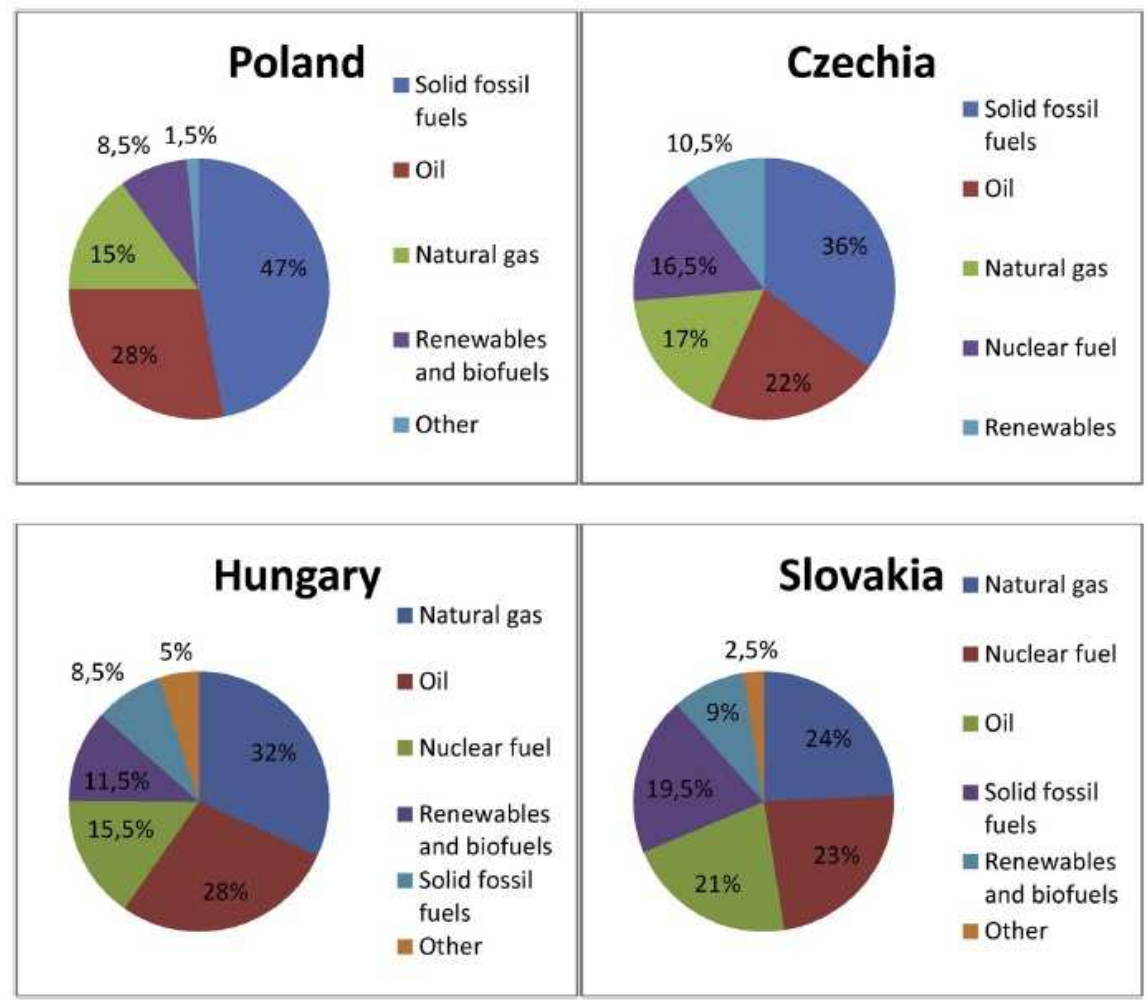

Fig. 3. V4 countries total primary energy supply (2017)

Source: European Commission, 2019. Energy datasheets [in:] Dyduch, Skorek).

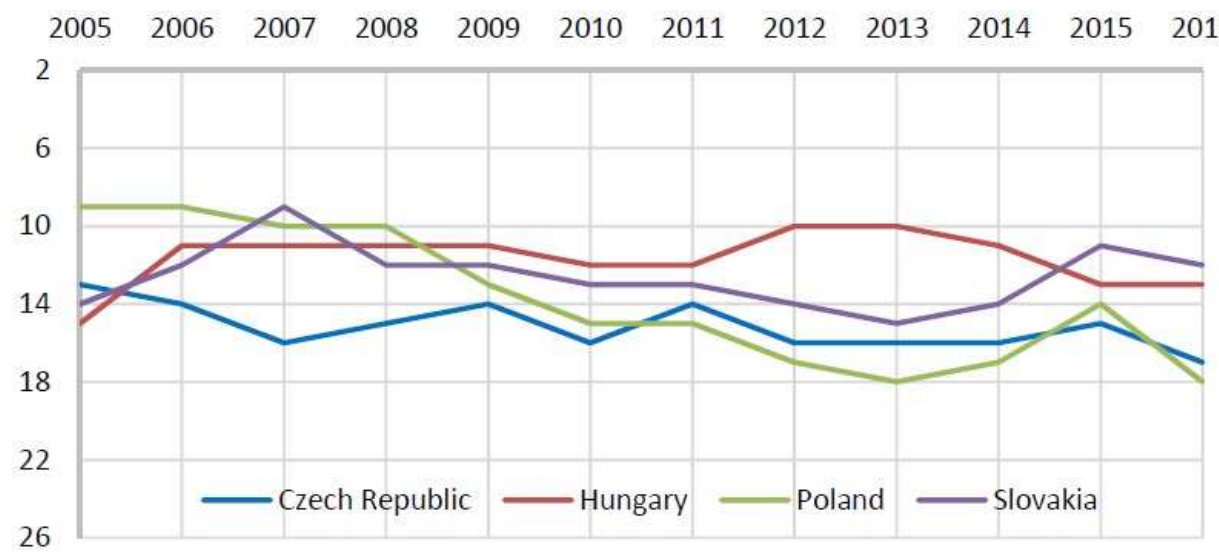

Fig. 4. The positions of the V4 countries in the ranking of achieving the 20-20-20 target in the years $2005-2016$

Source: (Pach-Gurgul, Ulbrych). 
Targets of percentage share of RES in Energy mix are being pressed up. For example, EU changed fixed value of RES share from $27 \%$ up until the end of 2030 (target set in 2014) to $32 \%$ in June 2018 . What is more, new agreement predicts an additional evaluation of matter and does not exclude possibility of another change of that factor in 2023 (European Commission. Renewable Energy. Moving towards a Low Carbon Economy). Energy and climate policy is still a fragile and delicate area for many East-Central European countries. It is needed to point the presence of many-sided geopolitical relationships with Energy resources suppliers, like Russia (Jirusek, 2020) or Germany. Existence under a central planning system caused domination of one Energy source in V4 countries. Also, there is a need to underline high energy intensity of national economies, centralization of the national energy markets, and dependence on Russia (Chodkowska-Miszczuk, Kulla, 2017) Energy supplies in many forms. V4 countries seek to adjust to the European market and standards, in which they need to address their diverse Energy possibilities and needs. Any fundamental transformation of EU energy and climate policy is thus discussed as a subject which should be part of broad dispute about the future of EU integration. The reason is obvious-energy ranks among the platform's top priorities and is appraised as the area in which it performs best (Zapletalová, Komínková, 2020).

\section{VISEGRAD COUNTRIES WIND ENERGY CHARACTERISTICS}

\subsection{Wind turbine installation potential}

While undertaking installation of wind-based power generators there exists an obvious consideration element which is a geographical specification (Kochanek, 2019). Potential of wind Energy highly depends on climate, which means the availability and wind, but also on the topography of the settlement, which directly affects wind velocity. Wind is a clean and free energy source that converts the kinetic energy created by airflows (using turbine) to power a generator supplying an electric current. There is a possibility of aggregating a number of turbines into windfarms that cover area of a few hectares of land or sea to „capture" both onshore and offshore wind (European Commision, Renewable Energy), which is a basic division of turbine installations. Offshore farms are estimated to produce $240-450 \mathrm{GW}$ of power by 2050 in order to keep global rise of temperature below $1,5^{\circ} \mathrm{C}$. Moreover, it is a set goal to achieve at least $50 \%$ of the total Energy mix produced from this type of generators in the same year, which states for $30 \%$ of future Energy demand. It is hard to imagine getting that kind of results by creating mostly onshore farms because of obvious weather and topographical reasons. Therefore, described solution may be a demanding task (if not impossible) for countries that do not have the access to open waters. It is natural to conclude that there exists (or does not) a capacity, ability to carry on development investments in wind Energy area.

Fig. 5 shows the Capacity Factor IEC Class I on the map for whole V4 region. The capacity factor is a measure of annual energy yield of a wind turbine, higher capacity factors indicate higher annual energy yield. Note that the capacity factor maps show estimated capacity factors and that each wind turbine site suitability must be considered separately. Red areas show places with high Factor value, which means higher Energy yield from a turbine installed there. Blue areas indicate lack of usable geographical opportunities for wind Energy production process. Averaging, most unfavorably situated in terms of production electricity from wind turbines in V4 group is Hungary, with Mean Power 


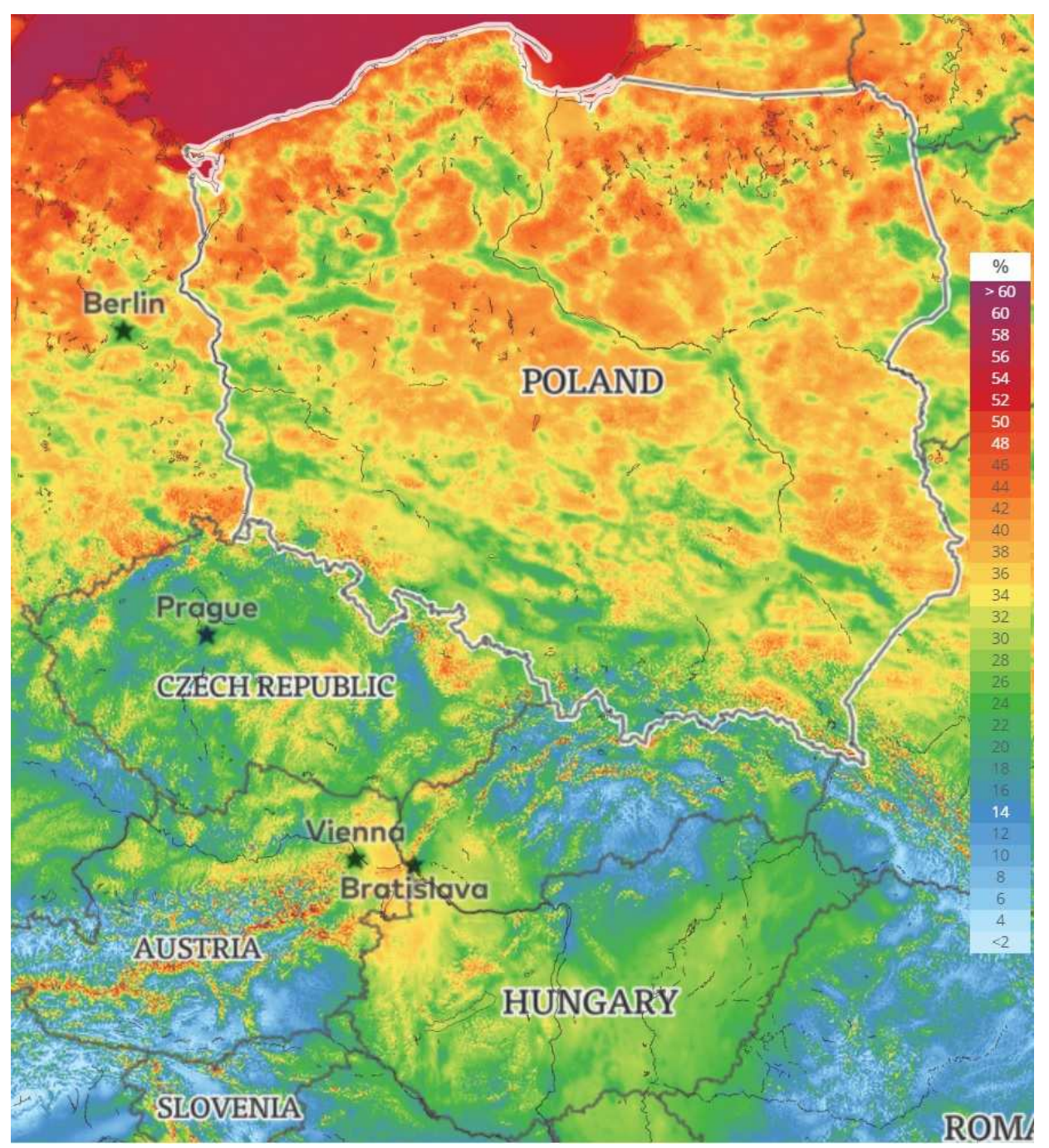

Fig. 5. Capacity Factor IEC Class I for Visegrad Group Countries source: globalwindatlas.info [Access: 08.05.2020].

Density for $10 \%$ windiest areas at height 100 meters at $375 \mathrm{~W} / \mathrm{m}^{2}$, secondly Poland at $478 \mathrm{~W} / \mathrm{m}^{2}$, Slovakia at $482 \mathrm{~W} / \mathrm{m}^{2}$ and Czechia at $486 \mathrm{~W} / \mathrm{m}^{2}$ (Global Wind Atlas). It needs to be underlined here that shown values do not give the full picture but just some numbers referring to the total country area. HUN, CZ and SK does not seem to have much potential to intensify wind Energy sector development because of the topography, where Poland shows a great variety of opportunities in that matter. 


\subsection{Wind Energy production}

The forecast for the structure of generation capacity in the V4 countries (Pach-Gurgul, Ulbrych, 2019) predicts an increase in the share of renewable energy in total demand between 2005 and 2020 by $6.6 \%$ in Poland, $11.7 \%$ in the Czechia, $13.1 \%$ in Hungary, and $8.5 \%$ in Slovakia. Nevertheless, the improvement in Poland and Slovakia is not high enough to meet the set goals in this respect.

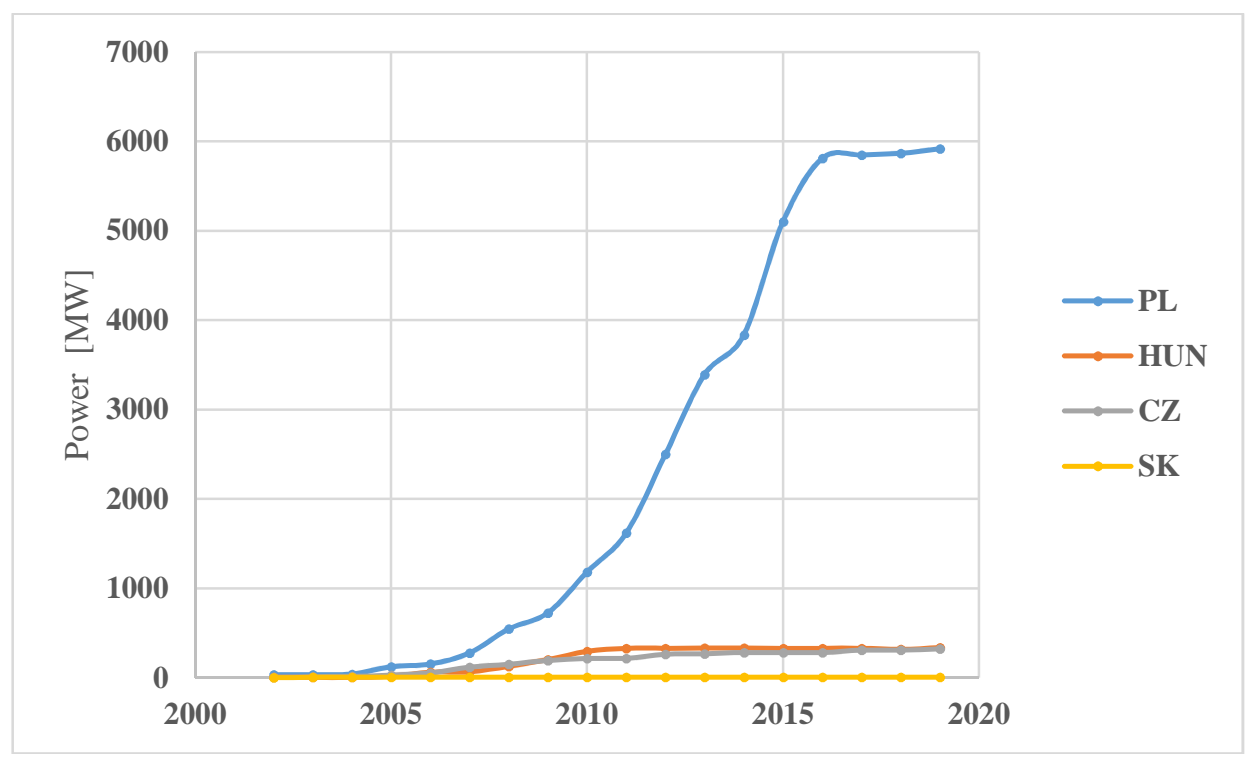

Fig. 6. Installed wind power capacity in Visegrad countries, source: own elaboration based on statistics $\left(\right.$ GWEC $^{3}$, WWINDEA ${ }^{4}$, EWEA (WindEurope) ${ }^{5}$ )

The installed wind power capacity changed mostly in Poland over years amongst V4 countries. It is an undisputable leader in this area of growth (fig. 6), where other members did not invest into wind Energy. This situation has two causes: lack of super-profitable installation areas that could yield highly from the turbines and access to other sources, like natural gas, oil or nuclear power. Poland still have not invested into a fully-pledged power plant based on nuclear reactions, which could be seen as a huge overlook of fixation of Energy mix in this country. Despite much faster growth of installed wind power capacity than rest of the members, Poland still does not meet EU requirements for a share of RES in that mix. It is also puzzling why the growth drastically reduced its' rate since 2015 , one might connect it to the change of government for a right-sided Prawo i Sprawiedliwość party, which had place that year - since then no huge investments have been attempted. It also needs underlining that most of the wind farms in Poland had been constructed using an foreign capital.

\footnotetext{
${ }^{3}$ Global Wind Energy Council, https://gwec.net/

${ }^{4}$ Wind Energy International, https://library.wwindea.org/

${ }^{5}$ EWEA (WindEurope), https://windeurope.org/
} 


\section{CONCLUSIONS}

Transition of Energy sectors in Visegrad countries is underway and its' further progress seems inevitable. Managing that process is mostly based on legislative actions, which coming from the EU pressure - should be deeply thought and get along with a long-term plan with a directly set goals. Main target of Energy transition management is to plan beforehand, create safe environment for development, lead and monitor increase of supply output and efficacy of the system and its' components, while focusing on an intelligent, sustainable development of crucial areas in Energy sector. Wind Energy - as such sector for Poland - still seems to have a great potential and if invested into, could lead to increase of RES share in Energy mix in this country. This cannot be said about other V4 members, where opportunities of wind Energy industry development do not show much optimistic perspective because of both geopolitical and environmental reasons. No access to open waters for onshore installations in Hungary, Czech and Slovakia excludes them from this kind of race.

All of the members need to lower their usage of fossil fuels, where Poland needs direct and strong action for its' greatest coal dependence compared to other Visegrad countries. Those factors could increase value of Energy security indexes, making this republic independent of coal imports (Russia, African countries) replaced by RES installations like wind farms. Czech, Slovak and Hungary members do not seek to increase their wind power capacity, looking elsewhere for satisfying their Energy needs, harvesting sources like nuclear power, oils or natural gas.

Transition policies in an Energy sector areas are essential factors for a smart, sustainable development of not only separate countries but also whole Visegrad region. Strong, common policy of V4 could provide beneficial additions in the context of EU legislative processes. Yet, it is not clear whether V4 countries share the same interest when it comes to their Energy needs, which is shown on voting (Ćetković, Buzogány, 2019).

\section{REFERENCES}

Chodkowska-Miszczuk, J., Kulla, M., Novotný, L. (2017). The role of energy policy in agricultural biogas energy production in Visegrad countries. "Bulletin of Geography. Socio-economic Series", Vol. 35.

Ćetković, S., Buzogány, A. (2019). The Political Economy of EU Climate and Energy Policies in Central and Eastern Europe Revisited: Shifting Coalitions and Prospects for Clean Energy Transitions Pages. "Politics and Governance”, Vol. 7. DOI: 10.17645/pag.v7i1.1786.

Directive (EU) 2018/2001 Of The European Parlament and Of The Council of 11 December 2018 on the promotion of the use of energy from renewable sources. "Official Journal of the European Union”. Access on the internet: http://data.europa.eu/eli/dir/2018/2001/oj. [Access 20.05.2020].

Dyduch, J., Skorek, A. (2020). Go South! Southern dimension of the V4 states' energy policy strategies - An assessment of viability and prospects. "Energy Policy", Vol. 140. DOI: 10.1016/j.enpol.2020.111372.

European Commission. Renewable Energy. Moving towards a Low Carbon Economy. Brussels. Access on the internet: https://ec.europa.eu/energy/en/topics/renewable-energy [Access: 10.05.2020].

European Commision, Renewable Energy. Access on the internet: https://ec.europa.eu/ energy/topics/renewable-energy/onshore-and-offshore-wind_en [Access: 08.05.2020]. 
EWEA (WindEurope), https://windeurope.org/ [Access: 08.05.2020].

Global Wind Atlas, globalwindatlas.info [Access: 08.05.2020].

Global Wind Energy Council, https://gwec.net/ [Access: 08.05.2020].

Jirusek, M. (2020). The attitude of the Visegrad Group Countries towards Russian Infrastructural Projects in the gas sector. "Energy Policy", Vol. 139. DOI: 10.1016/j.enpol. 2020.111340.

Kemp, R., Rotmans, J. (2004). Managing the transition to sustainable mobility, System innovation and the transition to sustainability. "Theory, evidence and policy". DOI:10.4337/9781845423421.00001.

Kern, F., Howlett, M. (2009). Implementing Transition Management as Policy Reforms: a Case Study of the Dutch Energy Sector. "Policy Sciences", 42(4). DOI: 10.1007/s11077-009-9099-x. Kochanek, E. (2019). Regional cooperation on gas security in Central Europe. "Polityka Energetyczna - Energy Policy Journal”, Vol. 22. DOI: https://doi.org/10.33223/epj/103667.

Koszewska, M., Militký, J., Mizsey, P., Benda-Prokeinova, R. (2015). Prospects of the Visegrad cooperation in promoting a sustainable consumption and production model. Comparative Analysis Of The Results Across Countries, Final report.

Osičkaa, J., Lehotskýa, L., Zapletalováa, V., Černocha, F., Dančák, B. (2018). Natural gas market integration in the Visegrad 4 region: An example to follow or to avoid?, "Energy Policy", Vol. 112.

Pach-Gurgul, A., Ulbrych, M. (2019). Progress of the V4 Countries towards the EU's Energy and Climate Targets in the Context of Energy Security Improvement. "Entrepreneurial Business and Economics Review”, Vol 7, No. 2. DOI: 10.15678/EBER.2019.070210.

Streimikiene, D., Kasperowicz, R. (2016). Review of economic growth and Energy consumption: A panel cointegration analysis for EU countries. "Renewable and Sustainable Energy Reviews, Vol. 59.

Sviteková, M., Pavolová, H., Hlavňová, B. (2014). An Energy Strategy in a Liberalized Environment in Slovakia. Progress in Sustainable Energy Vol II: Creating Sustainable Development”, Vol. 2.

Szlávik, J., Sebestyén Szép, T. (2017). Delinking of Energy Consumption and Economic Growth in the Visegrad Group. “Geographia Technica”, Vol. 12. DOI: 10.21163/GT_2017.122.12.

Tereszkiewicz, F. (2018). Visegrad Euroscepticism: Discursive Nodal Points in Eurosceptic Discourses Surrounding External Actions of the European Union. "Modelling the New Europe". DOI:10.24193/OJMNE.2018.26.10.

Wind Energy International, https://library.wwindea.org/ [Access: 08.05.2020]

Zapletalová, V., Komínková, M. (2020). Who is fighting against the EU's energy and climate policy in the European Parliament? The contribution of the Visegrad Group. "Energy Policy", Vol. 139. DOI: 10.1016/j.enpol.2020.111326.

DOI: $10.7862 /$ rz.2020.mmr.15

The text was submitted to the editorial office: June 2020.

The text was accepted for publication: June 2020. 